\title{
THE EFFECT OF FINANCIAL KNOWLEDGE AND THE USE OF E-MONEY TOWARD FINANCIAL BEHAVIOR OF UNDERGRADUATE STUDENTS FACULTY OF ECONOMICS YOGYAKARTA STATE UNIVERSITY
}

\author{
Meyliana Safitri \\ Program Studi Akuntansi, Universitas Negeri Yogyakarta \\ meyliasyaf@gmail.com \\ Ratna Candra Sari \\ Program Studi Akuntansi, Universitas Negeri Yogyakarta \\ Ratna_candrasari@uny.ac.id
}

\begin{abstract}
The Effect of Financial Knowledge and The Use of E-Money Toward Financial Behavior of Undergraduate Students Faculty of Economics Yogyakarta State University. This study aims to determine the influence of (1) Financial knowledge toward financial behavior of undergraduate students Faculty of Economics, Yogyakarta State University. (2) Knowing the influence of the use of e-money toward financial behavior of undergraduate students Faculty of Economics, Yogyakarta State University. This research was comparative causal study. The study sample was 217 respondents of the Faculty of Economics, Yogyakarta State University students. Samples were taken using purposive sampling technique. The data analysis technique used is multiple linear regression analysis test. The result of this study show that (1) Financial knowledge has a positive effect on financial behavior of undergraduate students Faculty of Economics, Yogyakarta State University. (2) The use of E-money has a negative effect on financial behavior of undergraduate students Faculty of Economics, Yogyakarta State University.
\end{abstract}

Keywords: Financial Knowledge, E-money, Financial Behavior

Abstrak: Pengaruh Pengetahuan Keuangan, Dan Penggunaan E-Money Terhadap Perilaku Keuangan Mahasiswa S1 Fakultas Ekonomi Universitas Negeri Yogyakarta. Penelitian ini bertujuan untuk mengetahui pengaruh (1) pengetahuan keuangan terhadap perilaku keuangan mahasiswa S1 Fakultas Ekonomi Universitas Negeri Yogyakarta. (2) Mengetahui pengaruh penggunaan e-money terhadap perilaku keuangan mahasiswa S1 Fakultas Ekonomi Universitas Negeri Yogyakarta. Penelitian ini merupakan penelitian hubungan kausal. Sampel penelitian ini adalah 217 responden mahasiswa Fakultas Ekonomi Universitas Negeri Yogyakarta. Sampel diambil menggunakan teknik purposive sampling. Teknik analisis data menggunakan uji analisis regresi linear berganda. Hasil penelitian menunjukan bahwa (1) Pengetahuan Keuangan, berpengaruh positif terhadap Perilaku Keuangan Mahasiswa S1 Fakultas Ekonomi Univeristas Negeri Yogyakarta. (2) Penggunaan e-money berpengaruh negatif terhadap perilaku keuangan mahasiswa S1 Fakultas Ekonomi Universitas Negeri Yogyakarta.

Kata kunci: Pengetahuan Keuangan, E-money, Perilaku Keuangan.

\section{PROBLEM BACKGROUND}

The development of the world economy and information technology is going very fast. The era of digitalization in various sectors marks the emergence of the new economic industry era. Changes in the dynamics of the economic movements that 


\section{Nominal: Barometer Riset Akuntansi dan Manajemen}

P-ISSN: 2303-2065 E-ISSN: 2502-5430

Volume 10 No 1 (2021)

were originally centralized in humans have experienced a slow yet sure shift by digitizing technology in moving the wheels of the economy called the industrial revolution 4.0 (Suwardana, 2017). At present, the utilization of development in the economy in the modern era emerges in business that has penetrated the online system, and also in the payment system (Vhistika, 2017). The main activities offered in Industry 4.0 are the convenience of a transaction, the fast of information obtained, and the existence of digital social networking through mobile devices that support and trigger individuals to change their way of thinking, lifestyle, self-existence, social culture, and financial behavior (Subawa and Widhiasthini, 2018).

One of the intelligences that must be possessed by modern humans to deal with the industrial revolution 4.0 is financial intelligence (Zahroh, 2014). Based on Worldmeters data in 2019, Indonesia has a population of 269 million people or $3.49 \%$ of the total world population, ranked as the fourth largest population in the world. The large population does not reflect the Indonesian's readiness for preparing the industrial revolution 4.0. One of the problems is the low financial intelligence as financial knowledge among Indonesian compared to other countries. According to research conducted by the Otoritas Jasa Keuangan, the level of financial literacy in Indonesia in 2019 was $38.03 \%$. It has increased compared to the previous survey by OJK, was about $29.7 \%$ in 2016. If compare to other countries, such as Singapore that has a financial literacy level of $96 \%$, Malaysia is $81 \%$, and Thailand is $76 \%$, Indonesia is still far behind. According to the Organization for Economic Co-operation and Development or OECD (2016) defines financial literacy as knowledge and understanding of financial concepts and risks, along with the skills, motivation, and confidence to apply their knowledge and understanding in order to make effective financial decisions, improve financial well-being of individuals and communities, and participate in the economic field. One of the things, which causes low financial literacy, is one's financial knowledge. As a result, Indonesian does not have sufficient knowledge about how to optimize using e-money for productive activities.

According to research conducted by PWC in 2014, with 5,500 respondents aged 23-35 years, showed that only $24 \%$ of respondents have sufficient financial knowledge. Financial knowledge, according to Kamus Besar Bahasa Indonesia, is a skill or ability in terms of finance. Financial knowledge possessed by a person then develops into financial skills, namely the 


\section{Nominal: Barometer Riset Akuntansi dan Manajemen}

P-ISSN: 2303-2065 E-ISSN: 2502-5430

Volume 10 No 1 (2021)

ability in applying financial knowledge in everyday life (Palameta et al., 2016). Financial knowledge is functions as a tool for someone's authority to make decisions in financial management, such as preparing a budget, choosing an investment, choosing an insurance plan, and attitude in using credit cards and e-money (Kholilah and Iramani, 2013). It is financial tools used in making financial decisions such as e-money, checks, credit cards, and debit cards (Humaira, 2018). Financial knowledge possessed by a person will affect the financial behavior of the person. According to Atkinson and Messy (2012), increasing one's financial knowledge can have an impact on active participation in finance, and responsible financial behavior. By this, the researcher guessed that there is an influence of financial knowledge toward financial behavior.

This time, young people need to have basic knowledge and skills to make important personal financial decisions (Chen $\&$ Volpe, 1998). Individuals with generating high income may experience financial problems due to lack of knowledge related to personal financial management. Consumers including students are irrationally buying needs in this consumption era (Nababan and Sadalia, 2017). Moreover, the increasingly widespread online shopping system and the development of a digital payment system in
Indonesia provide a convenience system, easily accessed on each individual's mobile device increase the high consumerism. One of the payment systems used for current economic development is by non-cash payment system (Vhistika, 2017). One noncash financial product is Electronic money (e-money). In principle, people who have emoney are the same as having cash converting into electronic form (Quthbi, 2016).

At present, millennial, including university students, require practical and instant ways in carrying out all activities. These characteristics will be an opportunity for the businessperson, especially providers of electronic money, both card-based, and server-based, by offering discount promos, practicality, and convenience transaction. Incessant promos offered by electronic money providers can draw many people's interest in using digital payments so that the use of e-money has increased. This can be seen from the data of Bank Indonesia, which recorded the number of electronic money transactions in 2018 of 2.92 billion, a threefold increased from 2017 of 943 million.

Based on the results of an online survey by SurveyOne together with Giladiskon, as reported by marketing.co.id, $62.5 \%$ of respondents revealed that they eat at a restaurant every week. In the past, 


\section{Nominal: Barometer Riset Akuntansi dan Manajemen}

P-ISSN: 2303-2065 E-ISSN: 2502-5430

Volume 10 No 1 (2021)

Indonesia tended to have home cooking and ate a homemade dish. At present, with the presence of e-money such as Gopay and OVO, eating in restaurants becomes a common lifestyle. It is due to the influence of discount promo information offered by mobile devices and social media applications. As many as $92.6 \%$ of the most popular promos of Indonesian people are restaurant promos. Behind the convenience of transactions and practicality offered, there are negative effects for users, namely susceptible to premature affluence. By this, the researcher suppose that the use of emoney will affect their financial behavior.

Reported by tirto.id according to Drazen Prelec, a professor from the Massachusetts Institute of Technology (MIT) said that credit cards or other non-cash payments are quite dangerous because of the potential effect making the users no longer feel the sense of loss or pain when purchasing. Therefore, in deciding for purchasing, an individual should behave rationally based logic, instead of irrationally so that they can distinguish within wants and needs (Warsono, 2010). If students cannot distinguish between needs and wants, it will have an impact on an unhealthy financial condition. This kind of conditions could be dangerous in managing finances so that it an effect on irresponsible financial behavior.
A lifestyle among adolescents raises a bad resource and financial management since a debt lifestyle, in which it can be easily obtained and can facilitate one's lifestyle, grows among teenagers or students (Arif, 2019). It rises an assumption that students have complex financial problems. The financial income of most students generates from parents. If the students encounter late transfer money, it will be one's problem. Students thus experience problems of limitations of the reserve funds used every month (Nababan and Sadalia, 2017). On the other hand, there is another group of students who get monthly generate income from parents, then set aside to learn to invest (Suryanto, 2017). Students, at the moment, must behave independently in finance and start making responsible decisions (Elliehausen et al. 2007).

Student behavior in spending money depends on financial knowledge possessed (Suryanto, 2017). Students, as young people, have better financial knowledge compared to the common people who have not get higher education (Arif, 2019). In reality, many young people or students are lack of financial knowledge. In line with research conducted by (Titik, 2016) which states that the level of financial literacy of students of the Faculty of Economics, Yogyakarta State University is only 57\%. Chen and Volpe (1998) categorize 
the financial literacy of students of the Faculty if Economics, Yogyakarta State University is low. Chen and Volpe (1998) categorize financial literacy into three groups, that if the level of financial literacy $<60 \%$ is low, $60 \%-70 \%$ is moderate, while more than $80 \%$ is high.

Students who are equipped with adequate financial knowledge will have better financial behavior, such as keeping records of expenses made monthly and have a reserve of funds for emergencies (Yulianti and Silvy, 2013). Also, they are able to use non-cash payment instruments such as emoney wisely. Based on the background of the study, the researcher was interested in conducting further studies and research to look at the financial behavior among students of Faculty of Economi, Yogyakarta State University related to the financial knowledge, and the use of e-money today through the research under the title: "The Effect of Financial Knowledge, and The Use of E-money Toward Financial Behavior of Undergraduate Students Faculty of Economics Yogyakarta State University.”

\section{LITERATURE REVIEW}

\section{a. Financial Behavior}

According to Nofsinger (2005), financial behavior is the study of how humans determine their finances (financial settings), specifically identifying psychological factors in financial decision making. Humans basically as social creatures that can not be separated from the process of interaction with others, which will underlie the emergence of decisions in taking action, including in the process of financial management. According to Zimmerere and Scarborough (2008), financial behavior is defined as the process of gathering, planning, forecasting, spending, and investing in income so that it can operate smoothly. Based on the understanding that has been described, it can be concluded that financial behavior is the ability of individuals to manage their finances starting from planning, budgeting, managing, spending, checking, controlling, and delivering daily funds for living needs.

\section{b. Financial Knowledge}

Financial Knowledge as part of financial literacy in the form of selfconfidence followed by the ability to understand finances so that ultimately it is used as a basis for financial decision making (Huston, 2010). Meanwhile, according to Lusardi (2008), Financial Knowledge as financial knowledge of students about the basic concepts of finance including knowledge of compound interest, differences in normal values and real values, basic knowledge about risk diversification, time value of money, and others. In research, Andrew and Linawati (2014) state that the 


\section{Nominal: Barometer Riset Akuntansi dan Manajemen}

P-ISSN: 2303-2065 E-ISSN: 2502-5430

Volume 10 No 1 (2021)

higher one's knowledge shows wise financial behavior. Individuals with low financial knowledge will make more mistakes in financial decision making, so Lusardi and Mithcell (2014) argue that Financial Knowledge is important to produce the right financial decisions. The role of financial knowledge in an individual's daily life is very important, not only providing general economic benefits but can provide a knowledge base for using money wisely (Putranti and Junarsin. 2019). Financial Knowledge in this study refers to Lusardi's theory (2008), which includes; (1) basic financial person; (2) financial management; (3) credit and debt management; (4) saving and investment; (5) risk management.

Financial knowledge can be a major factor in financial decision making for students. Student financial knowledge can be implemented in everyday life, such as: preparing a budget; choose investment; setting aside some money for the future, and limit spending. With financial knowledge, individuals will be wiser in making every financial decision related to the financial problems they face. Students can use the ability of financial knowledge to make financial decisions through financial tools. Financial tools are tools to use in making personal financial management decisions, such as checks, credit cards, debit cards, and e-money. Therefore, the better financial knowledge, the better financial behavior (Potrich, 2017). Putranti and Junarsin (2019) found that individuals who have financial knowledge are more likely to have directed financial behavior. Based on these explanations, it can be concluded that financial knowledge will affect financial behavior

\section{c. The Use of E-money}

Understanding e-money, according to PBI Number 11/12 / PBI / 2009 concerning Electronic Money, which is a means of payment that meets the following elements; (1) Issued based on the value of money paid in advance by the holder to the issuer; (2) The value of money is stored electronically in a medium such as a server or chip; (3) Used as a means of payment to traders who are not issuers of electronic money; and (4) The value of electronic money deposited by holders and managed by the issuer is not a deposit as referred to in the law governing banking.

In Hidayati (2006: 4), storedvalue or prepaid products in which a certain amount of money is stored in an electronic media owned by someone. Types of payment instruments are divided into two categories, namely prepaid products and access products. E-money is a type of prepaid product that is used for various purposes while debit and credit cards are examples of access products. 


\section{Nominal: Barometer Riset Akuntansi dan Manajemen}

P-ISSN: 2303-2065 E-ISSN: 2502-5430

Volume 10 No 1 (2021)

The characteristics of prepaid products, according to Hidayati (2006: 4) as follows; (1) The value of money recorded in e-money, called the stored value, will decrease when the e-money owner makes a transaction; (2) Funds recorded in emoney are fully the owner's rights. (3) At the time of the transaction, the transfer of funds in the form of electronic value from e-money to the merchant's terminal can be done offline. Verification is only done at the merchant level (point of sale), without having to go online to the e-money issuing computer.

\section{d. Mental Accounting Theory}

Understanding mental accounting can be associated with an understanding of accounting, where accounting is a system of recording, grouping, and financial reporting for decision making (Sari, 2017). Every financial transaction in a company will be recorded and grouped according to certain accounts. As with companies, individuals can also group their money into certain predetermined criteria (Sari, 2017). According to Thaler (1985), mental accounting is a series of cognitive operations that are used by individuals to organize, create categories, and evaluate financial activities.

Mental accounting refers to
individuals to allocate their money to savings, investments, needs, alms, and other expenses, making it easier to manage finances. However, this allocation can lead to irrational decisions and behavior, such as in the use of e-money. By using e-money, it is easier for a person to make transactions because in principle e-money is the same as having cash that is converted into electronic form. Someone who transacts with a noncash payment system has the potential to make users no longer feel the sense of loss or pain when paying. With the loss of pain when paying, people will tend to use it continuously so that it is possible to buy goods or services that are not needed.

Today, people are reluctant to carry large amounts of cash in their wallets or pockets because it is neither safe nor practical (Ramadhani, 2019). Moreover, e-money offers convenience, effectiveness and efficiency, as well as benefits in payment transactions. Thus, individuals will more easily spend their money in daily life or in meeting their needs, which will indirectly affect individual financial behavior.

The level of convenience and practicality offered can make the use of emoney vulnerable to mental accounting. Mental accounting in question is irrational behavior caused by the use of e-money. Noncash payments such as e-money have the potential to encourage individual consumption to be high because individuals 
no longer feel the sense of loss and pain when paying. Based on this explanation, it can be concluded that the use of e-money affects financial behavior

$\mathrm{H}_{1}=$ Financial knowledge has a positive effect toward financial behavior of undergraduate student faculty of economics yogyakarta state university.

$\mathrm{H}_{2}=$ The use of e-money has a negative effect toward financial behavior of undergraduate student faculty of economics yogyakarta state university.

\section{RESEARCH METHOD}

\section{Type of Research}

This research is quantitative research. The quantitative research method is a research approach that based on the philosophy of positivism, which is a school of philosophy that states natural science as the only source of actual knowledge, knows no speculation, and all based on empirical data. Research data in the form consist of numbers and data analysis using statistics (Sugiyono, 2017). This research is causal associative research. This type of associative research is research that asks about the relationship between two or more variables (Sugiyono, 2017)

\section{Place and Time Research}

This research will be conducted at Faculty of Economics, Yogyakarta State University (UNY). The time for conducting this research is October January - February 2020.

\section{Research Subject}

The population in this research were all Undergraduate Students in the Accounting and Management Study Program Faculty of Economics, Yogyakarta State University. The technique used in sampling in this study is by using a purposive sampling technique with several criteria. The sample criteria used in this study are:

a. Active students of the Undergraduate Accounting and Management Study Program, Faculty of Economics, Yogyakarta State University.

b. Already taking a course in Manajemen Keuangan.

c. Already currently using e-money.

Determination of the number of samples using the Slovin formula with an error rate of $5 \%$. The number of Undergraduate of Accounting and Management students of the Faculty of Economics of Yogyakarta State University who have met the criteria is 474 . Slovin's formula for determining the number of samples is:

$$
n=\frac{N}{1+N e^{2}}
$$

$$
n=\frac{474}{1+474 \times 0,05^{2}}
$$

$$
\mathrm{n}=216,93=\mathbf{2 1 7}(\text { rounded off })
$$




\section{Nominal: Barometer Riset Akuntansi dan Manajemen}

P-ISSN: 2303-2065 E-ISSN: 2502-5430

Volume 10 No 1 (2021)

Information:

$\mathrm{n}$ : Number of samples

$\mathrm{N}$ : Total population

e: Error level 5\%

There are 217 students were collected in this research.

\section{Techniques and Instruments Data Collection}

The data used in this study are primary data. The technique used to collect data in this study using a questionnaire The questionnaire is a way of collecting data by giving a set of written questionnaires to respondents to answer (Sugiyono, 2017). The research instrument used in this study was a closed questionnaire, so respondents only needed to provide a checklist $(\sqrt{ })$ on the alternative answers provided.

Measurements in Financial Knowledge variables in this research use a guttman scale with 1 for correct answers and 0 for wrong answers. Measurements on the use of e-money and financial behavior of undergraduate students Faculty of Economics Yogyakarta State University in this research used four-scale Likert Scale.

\section{Validity and Reliability of Instruments}

Validity is a measure that shows the level of validity/validity of an instrument. Valid instruments have high validity, and less valid instruments have low validity (Arikunto, 2010). In this research, to test the validity carried out by statistical techniques correlation formula between scores of items with a total score provided that if the value of $r$ count $>r$ table value then the statement item is declared valid.

Instrument reliability testing shows the extent to which the instrument can provide consistent measurement results if measurements are made repeatedly. Test instruments are said to be trustworthy if they provide consistent results when tested many times. In this research to conduct reliability tests carried out by calculating the Reliability number, then the number is interpreted with the level of correlation coefficient of the instrument. An instrument is said to be reliable if the Cronbach Alpha coefficient value is greater than 0.60 (a> 0.60 ) (Sugiyono, 2017).

Based on the results of the reliability test, the results obtained that the instrument of the use of e-money and financial behavior of undergraduate students Faculty of Economics Yogyakarta State University questionnaire is reliable.

\section{RESULT AND DISCUSSION}

\section{Data Analysis Techniques}

\section{Normality Test}

The normality test is carried out by looking at the value of Asymp. Sig. (2-tailed) using the Kolmogorov-Smirnov non- 
parametric statistical test. The variable is distributed normally if the significance value is higher than 0.05 . The result of the normality test is as follows:

Table 1: Data Normality Test Results

\begin{tabular}{llll}
\hline Variable $\quad$ Sig & $\begin{array}{l}\text { Asym Conclusion } \\
\text { Sig. (2- } \\
\text { tailed) }\end{array}$ & \\
\hline $\begin{array}{l}\text { Unstandardized } \\
\text { residual }\end{array}$ & 0,05 & 0,200 & Normal \\
\hline
\end{tabular}

Table 1, shows that the significance value of Kolmogorov-Smirnov is 0.200 . These results are greater than the significance value of 0.05 , and it can be concluded that the data of this study are normally distributed.

\section{Linearity Test}

Linearity Test is used to determine whether two variables have a linear relationship or not. If the significance of the Deviation from Linearity is less than 0.05 , it can be said that the variable is not linear. Following are the summary results of the linearity test:

Table 2: Data Linearity Test Results

\begin{tabular}{lcc}
\hline \multicolumn{1}{c}{ Variable } & Sig & Explanation \\
\hline $\begin{array}{l}\text { Financial } \\
\text { Knowledge }\end{array}$ & 0,753 & Linear \\
\hline $\begin{array}{l}\text { The Use of E- } \\
\text { money }\end{array}$ & 0,077 & Linear \\
\hline
\end{tabular}

Based on the table 2, the result of linearity tests shows that all independent variables have a sig of deviation from Inearity value of more than 0.05 . It can be concluded that all independent variables have a linear relationship to the dependent variable.

\section{Multicollinearity Test}

The results of the multicollinearity test can be seen from the value of the Variant Inflation Factor (VIF) and the tolerance value as follows:

Table 3: Multicollinearity Test

\begin{tabular}{lcc}
\hline Variable & Tolerance & VIF \\
\hline Financial Knowledge & 0,998 & 1,002 \\
\hline The Use of E-money & 0,998 & 1,002 \\
\hline
\end{tabular}

From the table 3 , it can be concluded that there is no multicollinearity between independent variables because the overall tolerance value is more than a 0.10 and the total VIF value is less than 10 .

\section{Heteroscedasticity Test}

Table 4: Heteroscedasticity Test.

\begin{tabular}{lcc}
\hline \multicolumn{1}{c}{ Variable } & $\begin{array}{c}\text { Sig Value } \\
\text { Critical }\end{array}$ & Sig \\
\hline $\begin{array}{l}\text { Financial } \\
\text { Knowledge }\end{array}$ & 0,05 & 0,708 \\
\hline $\begin{array}{l}\text { The Use of E- } \\
\text { money }\end{array}$ & 0,05 & 0,994 \\
\hline
\end{tabular}

Table 4 shows that the significance value of each variable has a value of more than 0.05, which means there is no heteroscedasticity in this research.

\section{Result of Hypothesis Test}

Hypothesis testing in this study will be carried out by multiple linear regression tests. Multiple linear regression tests will be conducted to test hypotheses one and two, 


\section{Nominal: Barometer Riset Akuntansi dan Manajemen}

P-ISSN: 2303-2065 E-ISSN: 2502-5430

Volume 10 No 1 (2021)

whether they are in line with the hypothesis expected by the researcher. The calculation results from multiple linear regression tests are the following table:

Table 5: Results of Multiple Linear Regression

\begin{tabular}{llcc}
\hline Information & $\begin{array}{l}\text { Regression } \\
\text { Coefficient }\end{array}$ & $\mathbf{t}$ & Sig \\
\hline Constant & 26.656 & 11.660 & 0,000 \\
Financial & 1.665 & & \\
Knowledge & & -2.134 & 0,034 \\
The Use of & $-0,179$ & & \\
$\begin{array}{l}\text { E-money } \\
\text { R Square }=0,400\end{array}$ & & \\
F value $=71,333$ & & \\
Sig. F $\quad=0,000$ & & \\
\hline
\end{tabular}

From the results of the Multiple Linear Regression testing above, the $\mathrm{R}$ Square value of 0,400 means $40 \%$ of Financial Behavior of Undergraduate Students Faculty of Economics Yogyakarta State University is influenced by Financial Knowledge, The Use of E-money, and other factors influence as much as $60 \%$. The hypothesis test equation can be written as follows:

$$
\mathrm{Y}=25.656+1,665 \mathrm{X}_{1}-0,179 \mathrm{X} 2+\mathrm{e}
$$

Based on the regression equation above, it can be seen that:

(1) The coefficient regression value of Financial Knowledge $\left(\mathrm{X}_{1}\right)$ is 1,665 , and the variable the use of e-money is considered constant then the financial behavior variable will increase by 1,665 points. The first hypothesis results indicate that $t$ count value of 11,660 is more than t table of 1.971 , with $\mathrm{p}$-value of 0.000 is less than 0.05 , it said the first hypothesis $\left(\mathrm{H}_{1}\right)$ is accepted. The results of this research are consistent with the results of research conducted by Bhushan and Mendury (2014), Tang and Baker (2016), Potrich et al. (2017), and Putranti and Junarsih (2019). Financial Knowledge can be a significant factor in financial decision making.

(2) The variable coefficient of the use of E-money $\left(\mathrm{X}_{2}\right)$ has a negative value of -0.179 , if the value of the use of E-money increases by 1 point and the variable Financial Knowledge is considered constant, then the Financial Behavior of undergraduate student faculty of economics Yogyakarta state university will decrease by 0.179 . The use of e-money variable has a $t$ count value of 2.134 is more than $\mathrm{t}$ table -1.971 , with $\mathrm{p}$ value of 0.034 is less than 0.05 , it said the second hypothesis $\left(\mathrm{H}_{2}\right)$ is accepted. The results of this research are consistent with the results of research conducted by Professor Drazen Prelec from the Massachusetts Institute of Technology (MIT) saying that credit cards or other non-cash payments including e-money are quite dangerous because they have the potential to make users feel no more loss or pain when paying, making them vulnerable exposed to wasteful behavior resulting in irresponsible Financial Behavior. 


\section{Discussion}

The first hypothesis proposed by researchers there is a positive effect of financial knowledge on Financial Behavior of Undergraduate Students Faculty of Economics Yogyakarta State University. The first hypothesis is proven by the results of testing multiple linear regression the sig variable financial knowledge shows p-value $0,000<0,05$. The result indicates that the first hypothesis was accepted. The regression coefficient is positive at 1.665 stating that the financial knowledge has a positive effect on Financial Behavior of Undergraduate Students Faculty of Economics Yogyakarta State University. With Financial Knowledge, individuals will be wiser in making every financial decision related to the financial problems they face. Therefore, the better the financial knowledge, the better the financial behavior. Someone with excellent financial knowledge will have more responsible financial behavior.

The second hypothesis proposed by researchers there is a negative effect of the use of e-money on the Financial Behavior of Undergraduate Students of the Faculty of Economics Yogyakarta State University. The second hypothesis was proven by the results of the analysis on the use of e-money test shows the sig value of variable X2 0,034< 0,05 which means that the hypothesis is accepted. It concluded that the use of emoney variable has a significant effect on Financial Behavior of Undergraduate Students of the Faculty of Economics Yogyakarta State University or the second hypothesis is accepted. The regression coefficient is negative at -0.179 stating that the use of e-money variable has a negative effect on financial behavior of Undergraduate Students of the Faculty of Economics Yogyakarta State University. Besides, following the theory of Mental Accounting according to Sari (2017) that Mental accounting refers to individuals to allocate their money into savings, investments, needs, alms, and other expenses, making it easier to manage finances. However, this allocation can lead to irrational decisions and behavior, as in the case of using e-money. By using e-money, it is easier for a person to make transactions because in principle e-money is the same as having cash that is converted into electronic form. Someone who transacts with a noncash payment system has the potential to make users no longer feel the sense of loss or pain when paying. With the loss of pain when paying, people will tend to use it continuously so that it is possible to buy goods or services that are not really needed. This shows that the use of e-money can form irresponsible financial behavior. 


\section{CONCLUSION AND SUGESSTION}

\section{Conclusions}

Based on the results and discussion in the previous chapter can be concluded as follows:

1) Financial Knowledge and the use of Emoney affect the Financial Behavior of Undergraduate Students Faculty of Economics at Yogyakarta State University. This is indicated by the significance value of $0,000 \quad(0,000$ $<0.05)$, the value of $f$ value 71,333 is more than $\mathrm{f}$ table 3.04, it can be concluded that the variable Financial Knowledge and the use of E-money simultaneously influence the Financial Behavior of Undergraduate Students Faculty of Economics Yogyakarta State University. From the results of multiple linear regression tests obtained an $\mathrm{R}$ Square of 0.400 which shows that the variable Financial Knowledge influences $40 \%$ and the use of e-money and as much as $60 \%$ is influenced by other factors not examined in this study.

2) The test results show that the first hypothesis (H1) is accepted, that is Financial Knowledge variable has a positive effect on the Financial Behavior of Undergraduate Students Faculty of Economics at Yogyakarta State University. This is indicated by t count of 11.660 is more than t table 1.917, with a level significance of $0,000(0,000$ $<0.05)$. The Financial Knowledge regression coefficient value is 1,665 , and it can be seen that if the value of Financial Knowledge increases by 1 point and the use of E-money is considered constant, then the Financial Behavior of Undergraduate Students Faculty of Economics Yogyakarta State University Students increases by 1.665 .

3) The test results show that the second hypothesis (H2) is accepted, that is The Use of E-money has a negative effect on the Financial Behavior of Undergraduate Students Faculty of Economics at Yogyakarta State University. Testing The Use of E-money has an effect on Financial Behavior has t count of -2.134 is more than -1.917 , with a level of significance of $0.034(0.034<0.05)$. The coefficient of the use of E-money has a negative value of -0.176 it can be seen that if the value of the use of E-money increases by 1 point, and Financial Knowledge is considered constant, then the Financial Behavior of Undergraduate Students Faculty of Economics Yogyakarta State University will decrease by 0.176 . This can be interpreted that the higher the use of Emoney, the Financial Behavior will be lower or can be construed to have an irresponsible Financial Behavior. 


\section{Suggestion}

1) For the student:

a) Students need to increase Financial Knowledge that can be obtained anywhere from various sources to have a more responsible Financial Behavior, so they can avoid financial problems.

b) Excessive use of e-money can expose users to destructive behaviors that irresponsibly result in Financia Behavior so use non-cash payment instruments wisely.

2) For Academics

Need to improve the quality of financial literacy, especially regarding financial knowledge to students so that it can help achieve one of the OJK targets in developing the Indonesian Financial Literacy National Strategy (SNLKI).

3) For Future Research

a) It is recommended that future researchers interested in researching this topic develop research with different variables that can affect Financial Behavior, can use variables such as financial attitude, personality type, parent socialization, locus of control, life satisfaction, and impulsive behavior.

b) Use a broader range of respondents so that they can reflect the population.

\section{REFERENCE}

Al-Kholilah, N. \& Iramani, (2013). Studi Financial Management Behavior Pada Masyarakat Surabaya. Journal of Business and Banking, 3(1): 69-80.

Andrew, V. \& Nanik, Linawati (2014). Hubungan Faktor Demografi dan Pengetahuan Keuangan Dengan Perilaku Keuangan Karyawan Swasta di Surabaya. FINESTA.Vol. 02. No. 02.

Arif, RM. (2019). Pengaruh Lotus of Control dan Financial Knowledge Terhadap Financial Management Behavior Mahasiswa FE UNY Kampus Wates. Tugas Akhir. Universitas Negeri Yogyakarta.

Arikunto, Suharsimi. 2010. Prosedur Penelitian Suatu Pendekatan Praktik Edisi Revisi 2010. Jakarta: PT. Rineka Cipta.

Atkinson, A. \& Messy, F. (2012). OECD Working Papers on Finance, Insurance and Private Pensions.

Bank Indonesia. (2009). Peraturan Bank Indonesia No.11/12/PBI/2009 - Uang Elektronik (Electronic Money). Bank Indonesia. Diakses pada laman http://www.bi.go.id/id/

Bhushan, P., \& Yajulu, M. (2014). An Empirical Analysis of Inter Linkages Between Financial Attitudes, Financial Behaviour and Financial Knowledge of Salaried Individuals. Indian Journal of Commerce \& Management Studies, Vol. V, Issue 3.

Chen, H., \& Volpe, R. P. (1998). An analysis of Financial Literacy among college students. Financial Services Review, 7(1), 107-128.

Data jumlah pengguna elektronik money di Indonesia. (Retrieved from www.bi.go.id ) 
Data jumlah penduduk Indonesia 2019. (Retrieved from www.worldometers.info ).

Definisi Financial Knowledge. (Retrieved from www.kbbi.web.id/).

Elliehausen, Gregory, E. Christopher Lundquist, and Michael E. Staten, (2007). The Impact of Credit Counseling on Subsequent Borrower Behavior. Journal of Consumer Affairs, 41 (1), 1-28.

Gumiwang, Ringkang. (2018). Candu Uang Elektronik para Milenial. (Retrieved from www.tirto.id )

Hidayati, S., Nuryanti, I., Firmansyah, A., Fadly, A., \& Darmawan, I. Y. (2006). Kajian Operasional Emoney. Tersedia di http://www.bi.go.id

Humaira, I. (2017). Pengaruh Pengetahuan Keuangan, Sikap Keuangan dan Kepribadian Terhadap Perilaku Manajemen Keuangan Pada Pelaku UMKM Sentra Kerajinan Batik Kabupaten Bantul. Skripsi. Universitas Negeri Yogyakarta.

Huston, SJ. (2010). Measuring Financial Literacy. The Journal of Consumer Affair Vol. 44 No. 2

Lusardi, A. (2008). Household Saving Behavior: The Role of Financial Literacy, Information, and Financial Education Program. NBER Working Paper 13824.

Lusardi, A., \& Mitchell, O. S. (2014). The Economic Importance of Financial Literacy: Theory and Evidence. Journal of Economic Literature, 52(1), 5- 44

Nababan, D., \& Sadalia, I. (2012). Analisis Personal Financial Literacy dan
Financial Behavior Mahasiswa Strata I Fakultas Ekonomi Universitas Sumatera Utara.

Nofsinger, \& John R. (2005). Psychology of Investing, Second Edition. New Jersey. Precentice-Hall Inc.

Otoritas Jasa Keuangan(OJK). (2017). Survei Literasi Keuangan.

Otoritas Jasa Keuangan. (2019). Siaran Pers Survei OJK 2019: Indeks Literasi dan Inklusi Keuangan Meningkat. https://www.ojk.go.id/id/berita-dankegiatan/siaran-pers/Pages/SiaranPers-Survei-OJK-2019-IndeksLiterasi-Dan-Inklusi-KeuanganMeningkat.aspx

OECD. (2016). PISA 2015 Assessment and Analytical Framework: Science, Reading, Mathematic and Financial Literacy. Paris: OECD Publishing.

Putranti, L. \& Eddy Junarsin. (2019). Tipe Kepribadian, Pengetahuan Keuangan, dan Perilaku Keuangan Individu. Thesis. Universitas Gadjah Mada.

PWC. (2014). Millennials \& Financial Literacy- The Struggle with Personal Finance. https://www.pwc.com/us/en/aboutus/corporateresponsibility/assets/pwc$\underline{\text { millennials-and-financial-literacy.pdf }}$

Palameta, B., Nguyen, C., Hui, T., \& Gyarmati, D. (2016). The Link Between Financial Confidence and Financial Outcomes Among Working-Aged Canadians. The Social Research and Demonstration Corporation (SRDC).

Potrich, A. C. G., Vieira, K. M., \& Kirch, G. (2017). How well do women do when it comes to financial literachy? Proposition of an indicatoor and 
analysis of gender differences. Journal of Behavioural and Experimental Finance.

Quthbi, Z.H. (2016). Pengaruh Kemudahan, Manfaat, Keamanan dan Privasi Kecukupan Informasi dan Kesenangan Bertransaksi terhadap Keputusan menggunakan E-Money pada Bus Trans Jogja. Skripsi. Universitas Islam Negeri Sunan Kalijaga.

Ramadhani, L. (2016). Pengaruh Penggunaan Kartu Drbit dan Uang Elektronik (E-money) Terhadap Pengeluaran Konsumsi Mahasiswa. JESP, 8(1).

Redaksi. (2017). Gopay dan Ovo Merajai Alat Pembayaran di Restoran. (Retrieved from www.marketing.co.id )

Sari, Ratna Candra. 2017. Akuntansi Keperilakuan: Teori dan Bukti Empiris. UNY Press: Yogyakarta.

Subawa, NS. \& Widhiasthini, NW. (2018). Transformasi Perilaku Konsumen Era Revolusi Industri 4.0. Conference on Management and Behavioral Studies. Universitas Tarumanagara.

Sugiyono. (2017). Metode Penelitian Kuantitatif, Kualitatif dan $R \& D$. Bandung: Alfabeta

Suryanto. (2017). Pola Perilaku Keuangan Mahasiswa Di Perguruan Tinggi. Jurnal Ilmu Ppolitik dan Komunikasi, Vol VII No. 1.

Suwardana, H. (2017). Revolusi Industri 4.0 Berbasis Revolusi Mental. JATI UNIK, Vol.1 No.2.

Titik, U., Umi SU., \& Rina SD. (2016). Tingkat Literasi Keuangan Mahasiswa Fakultas Ekonomi Universitas Negeri Yogyakarta
Tahun Angkatan 2012-2014. Jurnal Pelita, Vol. XI, No 2.

Thaler, R. (1985). Mental Accounting and Consumer Choice. Marketing Science, Vol. 4, No. 3, pp. 199-214

Vhistika, IN. (2017). Pengaruh Tingkat Pemahaman E-Money dan Kemanfaatan Terhadap Minat Menggunakan E-Money. Skripsi. Universitas Negeri Yogyakarta.

Warsono. (2010). Prinsip-Prinsip Dan Praktik Keuangan Pribadi. Jurnal Salam, Vol 13, No 2. Universitas Muhammadiyah Malang.

Yulianti, N., \& Silvy, M. (2013). Sikap Pengelola Keuangan Dan Perilaku Perencanaan Investasi Keluarga Di Surabaya. Journal of Business and Banking Vol. 3 No 1, Mei

Zahroh, F. (2014). Menguji Tingkat Pengetahuan Keuangan, Sikap Keuangan Pribadi, Dan Perilaku Keuangan Pribadi Mahasiswa Jurusan Manajemen Fakultas Ekonomika dan Bisnis Semester 3 Dan Semester 7. Skripsi. Universitas Diponegoro Semarang.

Zimmerer T. W, Norman M Scarborough. (2008). Kewirausahaan dan Manajemen Usaha Kecil. Salemba mpat 